\title{
Use of recombination in the production of influenza vaccine strains
}

\author{
D. MCCAHON* \\ B.Sc., Ph.D. \\ G. C. SCHILd \\ B.Sc., Ph.D. \\ Virology Division, National Institute for Medical Research, Mill Hill, London N.W.7
A. S. BEARE
M.R.C.Path.
T. S. HALL
M.D. \\ Clinical Research Centre, Harvard Hospital, Salisbury, Wiltshire
}

\begin{abstract}
Summary
Recombination between influenza $A$ viruses as a method of producing strains suitable for use in vaccines is discussed with particular reference to a recombination system involving an attentuated laboratory strain A/PR8/34 (HoN1) and a recent isolate of the epidemic strain A/Hong Kong/68 (H3N2). A variety of properties of the viruses were shown to be segregated independently of one another during recombination. These properties included the envelope antigens (haemagglutinin and neuraminidase), growth capacity in the fertile egg and attenuation for man. Some of the recombinants were considered suitable for use in vaccines either inactivated (whole virus particles or subunits) or live. The application of this technique to future requirements for vaccine strains are discussed with particular reference to the safety aspect of using recombinants in live vaccines.
\end{abstract}

\section{Introduction}

Although the phenomenon of high frequency genetic recombination among influenza viruses has been known for a long time (Kilbourne, 1963), it is only fairly recently that the idea of using this property to the disadvantage of the virus in the production of vaccine strains has been advocated (Kilbourne \& Murphy, 1960; Kilbourne, 1969). In the past, the process of adaptation has been widely used to make strains of virus suitable for use in vaccines but it is both tedious and unpredictable (Tyrrell \& Beare, 1969). Using the technique of recombination it has been possible to 'manufacture' rapidly and reproducibly strains of virus that are suitable either for use in inactivated (Kilbourne, 1969; McCahon \& Schild, 1972) or live attenuated vaccines. The properties which a vaccine strain must have to make it suitable for use in the production of the various types of vaccine are shown diagrammatically in Fig. 1.

* Present address: Virology Department, Wellcome Research Laboratories, Langley Court, Beckenham, Kent.
To illustrate how recombination can be used to fulfil these various requirements I shall refer in particular to an experiment which we described in 1972 (McCahon \& Schild) involving two human viruses, A/PR8/34 (HoN1) and A/Eng/939/69 (H3N2), and rather more briefly to various other recombination experiments involving other influenza A viruses of both human and animal origin.

\section{Materials and Methods \\ Viruses}

The parent viruses used in this study were Ao/ PR8/34 (HoN1) and A2/Eng/939/69 (H3N2) (kindly provided by Dr P. J. Wormald, Odstock Hospital, Salisbury).

\section{Recombination system}

The two viruses were recombined in the embryonated egg and clones were isolated at limit dilution as illustrated in Fig. 2. Prior to recombination the Ao parent virus was diluted 1 in 33 and inactivated to $1 \%$ survival of its original infectivity by ultraviolet light as described by Tumova \& Pereira (1965). This material was then diluted and $0 \cdot 1 \mathrm{ml}$ (10EID50) was inoculated into the allantoic sac of a 10-day-old embryonated egg. The egg was then inoculated with $0.1 \mathrm{ml}$ of neat allantoic fluid stock of the $\mathrm{A} 2$ parent virus $\left(10^{8} \mathrm{EID} 50\right)$ and incubated at $35^{\circ} \mathrm{C}$ for $15 \mathrm{hr}$.

\section{Limit dilution technique}

The limit dilution technique used both in the isolation and subsequent cloning of isolates was as follows: the virus preparation was treated in a Burndept ultra-sonic cleaner (input $80,000 \mathrm{~Hz}$ ) for $30 \mathrm{sec}$, diluted in two-fold or three-fold steps and then inoculated into 10-day-old embryonated eggs or allantois-on-shell cultures (AOS cultures) using a minimum of eight replicate cultures for each dilution. These AOS cultures were prepared and incubated according to the method described by Fazekas de St 


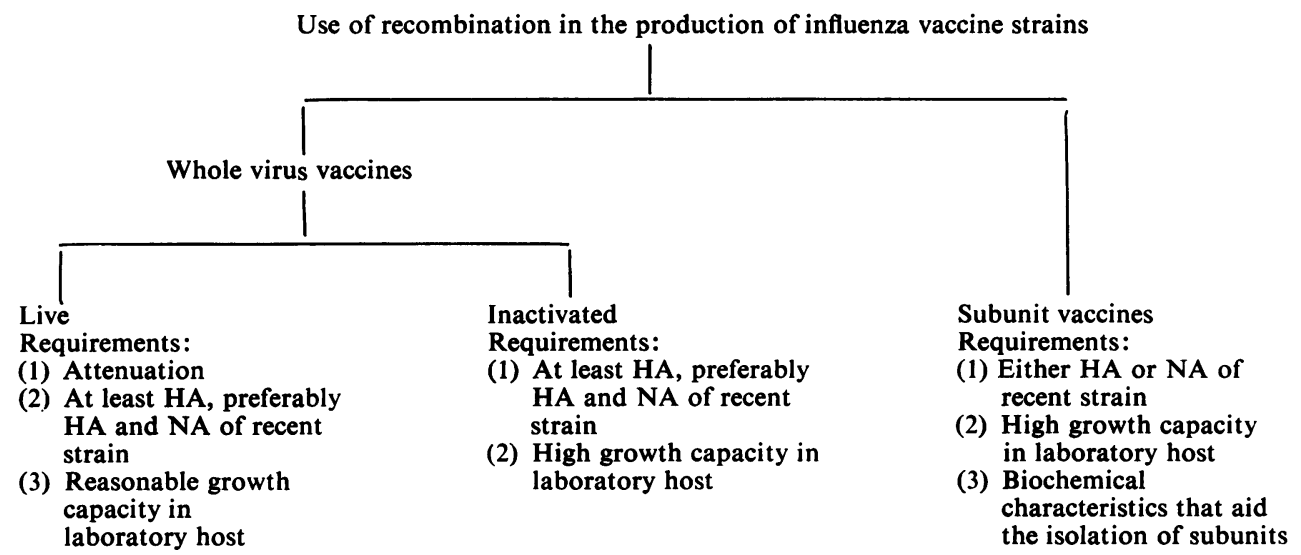

FIg. 1. Use of recombination in the production of influenza vaccine strains. HA, haemagglutinin antigen; NA, neuraminidase antigen.

Groth \& White (1958) except that the medium used was Leibovitz L15 (Leibovitz, 1963) to which had been added ampicillin $(250 \mathrm{~g} / \mathrm{ml})$ and amphotericin $B$ $(25 \mathrm{~g} / \mathrm{ml})$ and that the plates were individually sealed with 'Sellotape' and placed in polythene bags after the virus had been added. The limit dilution clones were isolated from cultures in which the virus dilution used infected only approximately $10 \%$ of the replicates as indicated by positive haemagglutination when tested with fowl erythrocytes. At least three clones of each isolate (usually from first and second limit dilution steps) were examined for Ao and $A 2$ characteristics in parallel with limit dilution clones from eggs which received either of the parent viruses.

\section{Serological techniques}

Haemagglutinin inhibitions tests were performed in plastic trays according to the technique described by the Expert Committee on Respiratory Virus Diseases (1959), except that serum-virus mixtures were kept for $1 \mathrm{hr}$ at room temperature before addition of the erythrocyte suspension.

Neuraminidase inhibition tests were done in test tubes as described by Webster \& Pereira (1968) except that the antiserum and neuraminidase were incubated for $1 \mathrm{hr}$ at $37^{\circ} \mathrm{C}$ followed by overnight incubation at $37^{\circ} \mathrm{C}$ with substrate.

\section{Mouse virulence}

Inoculum virus was diluted to contain $25 \mathrm{HAU} /$ 0.25 ml. Lung lesion scores in Parkes mice (5-7 weeks of age) were assessed 6 days after inoculation using the inoculation method and scoring system described by Horsfall (1939).

\section{Results}

'Manufacture' of recombinant vaccine strains

The method of 'manufacture' (i.e. recombination) which we have used in a variety of recombination experiments has two main features, (1) partial inactivation of the genome of one parent virus and

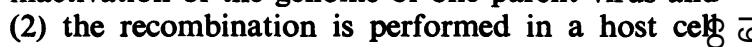
which is permissive for the partially inactivate ${ }^{\infty} \omega$ parent and restrictive for the other parent. In this way it is possible to induce two viruses which norm? ally have widely differing growth capacity to grow at approximately the same rate in the same cells and so enable recombination to occur. This system of recombination and the subsequent isolation and characterization of the recombinant viruses is illustrated in Fig. 2, which describes the experiment involving the two human viruses A/PR8/34 (HoN1) and A/Eng/939/69 (H3N2).

These two parent viruses were especially chosen for their distinctive properties: A/PR8/34 (HoN1) is a laboratory strain of influenza which grows to high titre in the embryonated hen's egg, is mouse pathogenic but is over attenuated for man (ten out of ten antibody-free volunteers could not be infected with this virus-Beare, unpublished); A/Eng/939/69 (H3N2) is a recent isolate of the current epidemic strain A/Hong Kong/1/68 (H3N2) which produces low yields of virus in eggs, is not pathogenic for mice $N$ and is virulent for man. Both the envelope antigens, $N$ haemagglutinin and neuraminidase, of the two parent $N$ viruses were distinct so that their identification in recombinant viruses was readily achieved.

At least three clones of each isolate (usually from first and second limit dilution steps) were examined for Ao and A2 characteristics in parallel with limit dilution clones from eggs which received either of the parent viruses. 


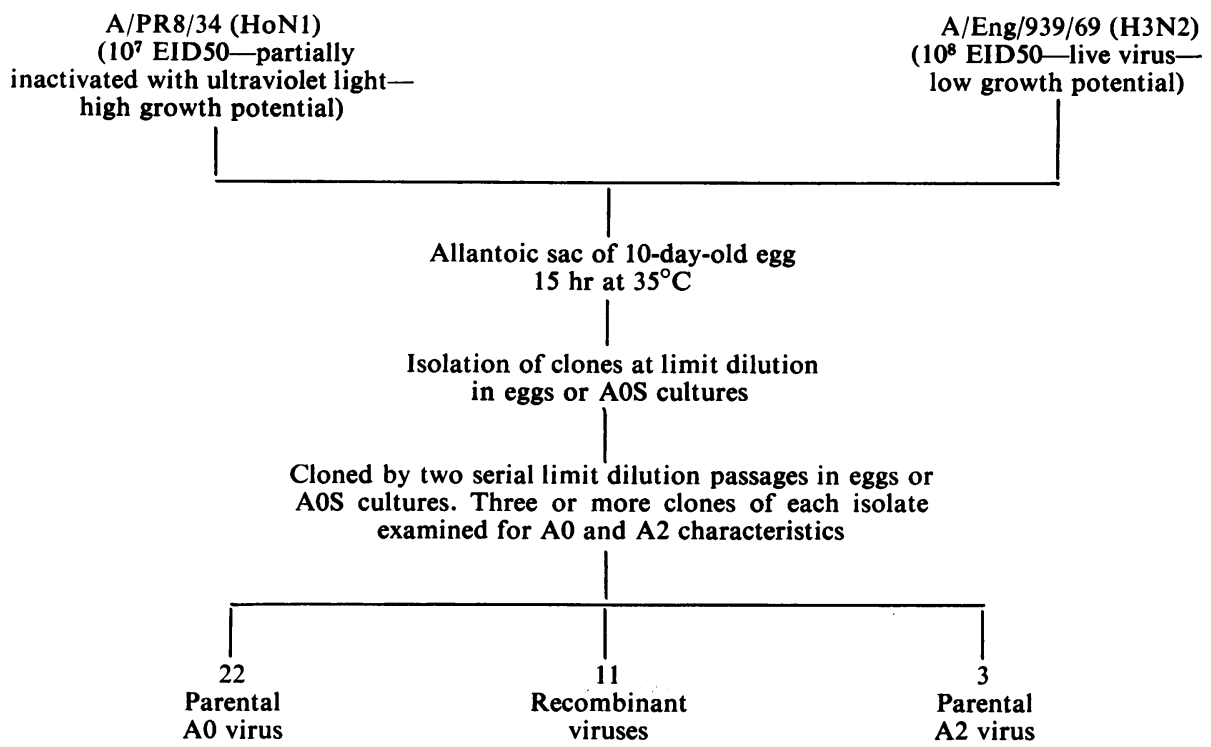

Fig. 2. Production and isolation of influenza virus recombinants.

Eleven out of thirty-six isolates derived from the mixedly infected eggs were recombinant on the basis of the four markers examined and eight different types of recombinant were found (Table 1).

The markers used were stable since the properties of all clones from any particular cloned isolate were identical.

\section{Examination of potential vaccine strains}

Four recombinants which had the characteristics of potential vaccine strains were further cloned and these additional clones were examined to further

TABLE 1. Types of recombinant isolated

\begin{tabular}{|c|c|c|c|}
\hline \multicolumn{4}{|c|}{ Genetic markers used* } \\
\hline $\begin{array}{l}\text { Haemagglutinin } \dagger \\
\text { antigen }\end{array}$ & $\begin{array}{c}\text { Neuraminidase } \\
\text { antigen }\end{array}$ & $\begin{array}{c}\text { Egg } \ddagger \\
\text { growth } \\
\text { capacity }\end{array}$ & $\begin{array}{c}\text { Mouse § } \\
\text { virulence }\end{array}$ \\
\hline $\begin{array}{l}\mathbf{H}_{3} \\
\mathbf{H}_{3} \\
\mathbf{H}_{3} \\
\mathbf{H}_{3} \\
\mathbf{H}_{0} \\
\mathbf{H}_{3} \\
\mathbf{H}_{3} \\
\mathbf{H}_{3}\end{array}$ & $\begin{array}{l}\mathrm{N}_{2} \\
\mathrm{~N}_{2} \\
\mathrm{~N}_{2} \\
\mathrm{~N}_{2} \\
\mathrm{~N}_{2} \\
\mathrm{~N}_{1} \\
\mathrm{~N}_{1} \\
\mathrm{~N}_{1}\end{array}$ & $\begin{array}{c}\text { High } \\
\text { Intermediate } \\
\text { High } \\
\text { Intermediate } \\
\text { High } \\
\text { High } \\
\text { Low } \\
\text { High }\end{array}$ & $\begin{array}{c}\text { Virulent } \\
\text { Virulent } \\
\text { Avirulent } \\
\text { Avirulent } \\
\text { Virulent } \\
\text { Avirulent } \\
\text { Avirulent } \\
\text { Virulent }\end{array}$ \\
\hline
\end{tabular}

* Three or more clones of each isolate were examined.

$\dagger$ These are based on haemagglutination and neuraminidase inhibition tests.

$\ddagger$ High growth capacity $=5120 \mathrm{HAU} / 0.25 \mathrm{ml}$, intermediate $=640-1280 \mathrm{HAU} / 0 \cdot 25 \mathrm{ml}$, low $=160 \mathrm{HAU} / 0 \cdot 25 \mathrm{ml}$ at $37^{\circ} \mathrm{C}$.

$\S$ Mouse virulence $=$ extensive pulmonary consolidation after intranasal inoculation of 10 to 1 HAU (Horsfall, 1939). check the stability of the antigenic and biological characters of these recombinants. All clones of any isolate had the same properties and the characteristics of the four different types of recombinant vaccine strains are shown in Table 2.

Since the difference between recombinants 6 and $64 \mathrm{c}$, and 7 and $64 \mathrm{~d}$ was based on only a small difference in growth capacity in eggs, this property was studied further by comparing their growth at various temperatures in AOS cultures with that of the parent viruses (Fig. 3) and this confirmed that these viruses differed from their parent viruses and each other in this property. The results for recombinants 6 and $64 \mathrm{c}$ are not shown on the figure since they closely resembled 7 and $64 d$ respectively.

These four recombinants were also tested in volunteers (Beare \& Hall, 1971) and all four were fully infective for man although of varying virulence. Two of the four recombinants were sufficiently attenuated to be regarded as suitable for use in live vaccine.

\section{Discussion \\ Problems and future requirements}

The technique of recombination has two great advantages over the more traditional method of adaption of virus strains, namely it is faster and more predictable. Strains derived by recombination are very suitable for use in inactivated vaccines (either whole virus or subunits) and with increasing knowledge of the genetics of the virus it may be possible to manufacture strains not only with the initial requirements of correct envelope antigens and good 
TABLE 2. Potential vaccine strains

\begin{tabular}{|c|c|c|c|c|c|}
\hline \multirow[b]{2}{*}{$\begin{array}{c}\text { Strain } \\
\text { designation }\end{array}$} & \multicolumn{5}{|c|}{ Genetic markers used* } \\
\hline & Haemagglutinin $\dagger$ & Neuraminidase $\dagger$ & $\begin{array}{c}\text { Egg growth } \\
\text { capacity at } 37^{\circ} \\
(\mathrm{HAU} / 0.25 \mathrm{ml})\end{array}$ & $\begin{array}{c}\text { Mouse virulence } \\
\text { (lung lesion } \\
\text { score) }\end{array}$ & $\begin{array}{c}\text { Human§ } \\
\text { attenuation }\end{array}$ \\
\hline $\begin{array}{l}\text { Recombinants: } \\
\quad 6\end{array}$ & $\mathbf{H}_{3}$ & $\mathrm{~N}_{2}$ & $2560-5120$ & $2 \cdot 5-3 \cdot 5$ & $\begin{array}{c}\text { Intermediate } \\
\text { virulence }\end{array}$ \\
\hline 7 & $\mathbf{H}_{3}$ & $\mathrm{~N}_{2}$ & $2560-5120$ & $0-0 \cdot 6$ & $\begin{array}{l}\text { Intermediate } \\
\text { virulence }\end{array}$ \\
\hline $\begin{array}{l}64 c \\
64 d\end{array}$ & $\begin{array}{l}\mathrm{H}_{3} \\
\mathrm{H}_{3}\end{array}$ & $\begin{array}{l}\mathrm{N}_{2} \\
\mathrm{~N}_{2}\end{array}$ & $\begin{array}{l}640-1280 \\
640-1280\end{array}$ & $\begin{array}{r}2 \cdot 1-2 \cdot 2 \\
0-0 \cdot 6\end{array}$ & $\begin{array}{l}\text { Attenuated } \\
\text { Attenuated }\end{array}$ \\
\hline $\begin{array}{l}\text { Parent viruses: } \\
\text { A/PR8/34 } \\
\text { A/ENG/939/69 }\end{array}$ & $\begin{array}{l}\mathrm{Ho} \\
\mathrm{H}_{3}\end{array}$ & $\begin{array}{l}N_{1} \\
N_{2}\end{array}$ & $\begin{array}{c}2560-5120 \\
32-128 \\
\end{array}$ & $\begin{array}{r}2 \cdot 5-3 \cdot 6 \\
0-0 \cdot 8 \\
\end{array}$ & $\begin{array}{l}\text { Attenuated } \\
\text { Virulent }\end{array}$ \\
\hline
\end{tabular}

* Three or more clones of each isolate were examined.

$\dagger$ These are based on haemagglutination and neuraminidase inhibition tests.

$\ddagger$ Inoculum virus was diluted to contain 25 HAU/0.25 ml . Lung lesion scores in Parkes mice (5-7 weeks of age) were assessed 6 days after inoculation using the inoculation method and scoring system described by Horsfall (1939). The range of values in tests with at least three clones of each recombinant or parent virus strain are given.

$\S$ Tested in volunteers (Beare \& Hall, 1971).

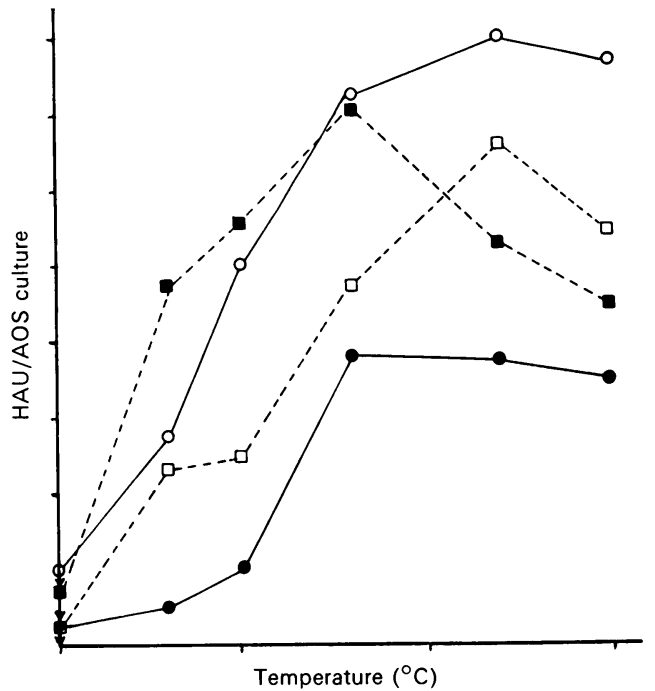

FIG. 3. The effect of temperature on the growth capacity of parent and recombinant viruses in AOS cultures. AOS cultures (approximately $3 \times 10^{5}$ cells) were infected with 2 HAU of virus and incubated with shaking in water baths at the temperatures shown for $24 \mathrm{hr}$. The haemagglutinin produced was measured after the cultures were frozen and thawed and treated with ultrasonic vibration. Each point represents the average value for two replicate cultures: $\mathrm{O}-\mathrm{O}$, Ao parent virus; $0-0$, A2 parent virus; $\square---\square$, recombinant virus $7 ; 0 .--\square$, recombinant virus $64 \mathrm{~d}$. This figure is reproduced by kind permission of the Journal of General Virology, where it was first published.

growth but also with more sophisticated requirements such as stability of the antigens to detergents which would be useful in the production of subunit vaccines.
However, the use of recombinants for live vaccine has two main problems: (1) stability of the recombinant virus and (2) the pedigree of the attenuated parent virus.

(1) Stability of the recombinant virus. This problem is not unique to recombinant viruses since the problem also arises with adapted viruses but there are additional overtones in the use of recombinanto viruses principally because we do not yet understand? how the recombination process occurs and how 'normal' the recombinant viruses are. However, the evidence from genetic studies such as we have described here and more extensive ones that we have done using avian and human influenza viruses (unpublished observations) and from other laboratories (Kilbourne, 1963) suggests that recombination occurs by the independent segregation of the pieces of the influenza parental genomes during replication in the same cell. Biochemical and antigenic studies on recombinant influenza viruses such as those by Laver (Kilbourne et al., 1967; Laver \& Webster, 1972) and by ourselves (Easterday et al., 1969; McCahon \& Schild, 1971; McCahon \& Skehel, unpublished observations) support the idea that such viruses are normal in the sense that they apparently have the normal complement of RNA, protein and antigens. Therefore, such viruses could be expected to be as stable as any adapted strain.

(2) Pedigree of the attenuated parent virus. The problem of what virus to use as the donor of attenuation is unique to recombinant viruses. The ideal parent would be one which had a known passage history preferably in leucosis-free embryonated hen's eggs and has not been passaged in animals or in undesirable tissue culture systems such as monkey kidney. In addition this virus should have 
reasonably good growth capacity in the host cell system used for the production of vaccine and, of course, it should be attenuated for man. The attenuation should be due to multiple defects, which can be identified, in regions of the genome other than those coding for the haemagglutinin and neuraminidase so that when recombined with the new epidemic variant, the attenuated strains could be examined for possession of these defects in the laboratory before testing in man. Such requirements imply a degree of sophistication in genetic techniques which we have not yet attained but which is certainly our goal.

\section{Acknowledgments}

We would like to thank Dr H. G. Pereira and Dr D. A. J. Tyrrell for their advice and encouragement during the course of this work and $\mathrm{Mr}$ B. Precious and Mr R. Newman for technical assistance.

\section{References}

Beare, A.S. \& Hall, T.S. (1971) Recombinant influenza A viruses, live vaccines for man. Lancet, ii, 1271 .

Expert Committee on Respiratory Virus Diseases (1959) First report. World Health Organization Technical Report Series 170 .

Easterday, B., Laver, W.G., Pereira, H.G. \& Schild, G.C. (1969) Antigenic composition of recombinant virus strains produced from human and avian influenza $A$ viruses. Journal of General Virology, 5, 83.

Fazekas de St Groth, S. \& White, D.O. (1958) An improved assay for the infectivity of influenza viruses. Journal of Hygiene, 56, 151.
Horsfall, F.L. (1939) Neutralization of epidemic influenza virus. Journal of Experimental Medicine, 70, 209.

Kilbourne, E.D. (1963) Influenza virus genetics. Progress in Medical Virology, 5, 79.

Kilbourne, E.D. (1969) Future influenza vaccines and the use of genetic recombinants. Bulletin of the World Health Organization, 41, 643.

Kilbourne, E.D., Lief, F.S., Schulman, J.L., Jahiel, R.I. \& LAVER, W.G. (1967) Antigenic hybrids of influenza virus and their implications. Perspectives in Virology, 5, 87.

Kilbourne, E.D. \& MurPhy, J.S. (1960) Genetic studies of influenza viruses. I. Viral morphology and growth capacity as exchangeable genetic traits. Journal of Experimental Medicine, 111, 387.

Laver, W.G. \& Webster, R.G. (1972) Studies on the origin of pandemic influenza II. Peptide maps of the light and heavy polypeptide chains of the haemagglutinin subunits of $A_{2}$ influenza virus isolated before and after the appearance of Hong Kong influenza. Virology, 48, 445.

Leibovitz, A. (1963) The growth and maintenance of tissuecell cultures in free gas exchange with the atmosphere. American Journal of Hygiene. 78, 173.

McCahon, D. \& Schild, G.C. (1971) An investigation of some factors affecting cross-reactivation between influenza A viruses. Journal of General Virology, 12, 207.

McCahon, D. \& Schild, G.C. (1972) Segregation of antigenic and biological characteristics during influenza virus recombination. Journal of General Virology, 15, 73.

Tumova, B. \& Pereira. H.G. (1965) Genetic interaction between influeuza $\mathrm{A}$ viruses of human and avian origins. Virology, 27, 253.

Tyrrell, D.A.J. \& Beare, A.S. (1969) Some studies on the selection and efficiency of live influenza vaccine viruses. Bulletin of the World Health Organization, 41, 581.

Webster, R.G. \& Pereira, H.G. (1968) A common surface antigen in influenza viruses from human and avian sources. Journal of General Virology, 3, 201. 